\title{
In Silico Three Dimensional Pharmacophore Models to Aid the Discovery and Design of New Antimalarial Agents
}

\author{
Apurba K. Bhattacharjee*, Mark G. Hartell, Daniel A. Nichols, Rickey P. Hicks, \\ John E. van Hamont, and Wilbur K. Milhous \\ Department of Medicinal Chemistry, Division of Experimental Therapeutics, \\ Walter Reed Army Institute of Research, 503 Robert Grant Avenue, \\ Silver Spring, MD 20910, U.S.A. \\ apurba.bhattacharjee@na. amedd.army.mil
}

\begin{abstract}
Malaria is one of the most dangerous diseases affecting primarily poor people of tropical and subtropical regions. The search for novel drugs against specific parasites is an important goal for antimalarial drug discovery. This study describes how 3D pharmacophores for antimalarial activity could be developed from known antimalarials and be used as screening tools for virtual compound libraries to identify new antimalarial candidates with examples of indolo[2,1-b]quinazoline-6,12-diones (tryptanthrins) that exhibited in vitro activity below $100 \mathrm{ng} / \mathrm{mL}$. These models mapped on the potent analogues and also onto other well-known antimalarial drugs of different chemical classes including quinolines, chalcones, rhodamine dyes, Pfmrk CDK inhibitors, malarial KASIII inhibitors, and plasmepsin inhibitors. The pharmacophores allowed search and identification of new antimalarials from in-house multi-conformer 3D CIS database and enabled custom designed synthesis of new potent analogues that are found to be potent against in vitro W2, D6, and TM91C235 strains of P. falciparum.
\end{abstract}

\section{Introduction}

Malaria, one of the most severe of the human parasitic diseases, causes about 500 million infections worldwide and approximately 3-5 million deaths every year. The search for novel antimalarial drugs against specific parasitic targets is an important goal for antimalarial drug discovery. [1] The situation is rapidly worsening mainly due to non-availability of effective drugs and development of drug resistance of a large number of non-immune people in areas where malaria is frequently transmitted. [1] Chloroquine, mefloquine, and other frontline drugs for the treatment and prevention of malaria, are becoming increasingly ineffective. [1] Artemisinin analogues such as artesunate and arteether were later introduced and found to be quite effective, particularly against drug-resistant $P$. falciparum, but observations of drug-induced and dose-related neurotoxicity in animals have raised concern about the safety of these compounds for human use.[2,3] Therefore, much effort and attention are needed for discovery and development of new and less toxic antimalarial drugs.

Indolo[2,1-b]quinazoline-6,12-dione, known as tryptanthrin, is an alkaloid isolated from the Taiwanese medicinal plant Strobilanthes cusia, and its substituted 
derivatives (Table 1) were recently studied at the Walter Reed Army Institute of Research, Silver Spring, Maryland, U.S.A.[4] and found to have remarkable in vitro antimalarial activity against $P$. falciparum, both sensitive and multidrug-resistant strains. The more potent analogs exhibit IC50 values in the range 0.43 to $10 \mathrm{ng} / \mathrm{mL}$, about one one-thousandth of the concentrations necessary to inhibit bacteria. Furthermore, the compounds are also found to be highly potent against strains of $P$. falciparum that are up to 5000-fold resistant to atovoquone, 50-fold resistant to chloroquine, and 20-fold resistant to mefloquine. Thus, this novel class of compounds has opened a new chapter for study in the chemotherapy of malaria.

Computer assisted molecular modeling (CAMM) has made remarkable progress in recent years in the design and discovery of new potential bioactive chemical entities.[5] The current advances in these methodologies allow direct applications ranging from accurate $a b$ initio quantum chemical calculations of stereoelectronic properties, generation of three-dimensional pharmacophores, virtual database searches to identify potent bioactive agents, to simulate and dock drug molecules in the binding pockets of proteins that are crucial and directly related to biomedical research.

In continuation of our efforts to design and discover new antimalarial therapeutic agents using computational methodologies [6,7], we present here our reported [4] 3D chemical feature based pharmacophore model and its utility as a tool for 3D database searches for identification of new structurally different classes of compounds for further study.

\section{Results and Discussion}

Three-dimensional pharmacophore for antimalarial activity was found to contain two hydrogen bond acceptor (lipid) functions and two aromatic hydrophobic functions at a specific geometric positions (Fig. 1) of the tryptanthrins was reported by us earlier. [5] The pharmacophore was developed using the CATALYST methodology [8] from a set of 17 structurally diverse tryptanthrin derivatives including the parent compound as the training set shown in Table 1. The correlation between the experimental and predicted activity of these compounds were found to be as $\mathrm{R}=0.89$. The more potent analogs of the training set (Table 1) such as $\underline{1}$ and $\underline{4}$ map well with the pharmacophore (Fig. 2a \& 2b) whereas, the less potent analogues such as $\underline{\mathbf{1 1}}$ and $\underline{\mathbf{1 6}}$ do not map adequately with the hypothesis (Fig. 2c \& 2d). Cross-validation of the generated pharmacophore was carried out by preparing a "test set" of 15 additional tryptanthrin compounds (Table 1) that were tested for in vitro antimalarial activity against D6 and W2 clones of $P$. falciparum identical to the original training set. The predicted and the experimental IC50 values for the test set tryptanthrins are found reasonably well reproduced [4], correlation as $\mathrm{R}=0.92$, within the limits of uncertainty [3], thus demonstrating the predictive power of the original pharmacophore. As observed in the training set, the more potent analogues of the test set such as $\underline{\mathbf{y}^{\prime}}$ and $\underline{11}$ ' map well (Fig. 3a \& 3b) with the pharmacophore whereas, the less potent analogues of the test set do not map adequately.

To further examine the validity of the pharmacophores, its features were mapped onto a series of eight antimalarial drugs that are currently used in the United States [3]; viz., quinine, chloroquine, mefloquine, primaquine, hydroxychloroquine, 
pyrimethamine, sulfadoxine, and doxycycline (Fig. 4). The mapping indicates that quinine completely satisfies the requirement with the pharmacophore (Fig. 4a) whereas, the other drugs map in varying degrees. It may be worthwhile to mention here that quinine and other quinoline-containing antimalarials including chloroquine have shown varying capacity to inhibit malaria heme polymerase extracted from $P$. falciparum tropozoites. [9] In particular, the interaction of quinine with heme has been well documented. [10] Since the pharmacophore maps well on quinine and in varying degrees on the other quinoline-containing antimalarials, it may be reasonable to speculate that the tryptanthrin compounds may target heme polymerase from the $P$. falciparum tropozoites. Preliminary results from NMR experiments on select tryptanthrin analogues have shown positive indications toward inhibition of the hemin polymerization process (unpublished results). In addition, we have also mapped the pharmacophore on a few recently reported potent antimalarials such as the chalcones11 and rhodacyanine dyes. [12] Surprisingly again, the more potent chalcone analogues such as, 2',3',4'-trimethoxy-4-trifluoromethyl and 2',4'-dimethoxy-4-ethyl chalcones (Fig 5a \& 5b) and the rhodacyanine dye MKT-077 and its para analogue map well on to the tryptanthrin pharmacophore (Fig 6a \& Fig 6b). In addition, the pharmacophore led to a search of the in-house multiconformer 3D databases that led to the identification of a fairly potent plasmepsin inhibitor: 6-diethylamino-2,3diphenylbenzofuran, two excellent Pfmrk inhibitors from the tryptanthrin classes, such the 8-nitro- and 7-chloro-4-azatryptanthrins, and a moderately good inhibitor, 4(benzenesulfonamido)-salicylic acid for the malarial KASIII enzyme. [4]

Table 1. Structure of Tryptanthrins

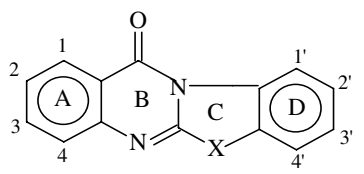

\begin{tabular}{|c|c|c|c|c|c|c|c|c|c|}
\hline \# & 1- & $2-$ & 3- & 4- & $\mathbf{X}$ & $1 '$ & 2 & 3' & 4 \\
\hline \multicolumn{10}{|c|}{ Training set: } \\
\hline 1 & $\mathrm{CH}$ & $\mathrm{CH}$ & $\mathrm{CH}$ & $-\mathrm{N}=$ & $\mathrm{C}=\mathrm{O}$ & $\mathrm{CH}$ & $\mathrm{CH}$ & $\mathrm{C}-\mathrm{Cl}$ & $\mathrm{CH}$ \\
\hline 2 & $\mathrm{CH}$ & $\mathrm{CH}$ & $\mathrm{C}-\mathrm{F}$ & $-\mathrm{CH}$ & $\mathrm{C}=\mathrm{O}$ & $\mathrm{CH}$ & $\mathrm{CH}$ & $\mathrm{C}-\mathrm{Cl}$ & $\mathrm{CH}$ \\
\hline \multirow[t]{2}{*}{3} & $\mathrm{CH}$ & $-\mathrm{N}=$ & $\mathrm{CH}$ & $\mathrm{CH}$ & $\mathrm{C}=\mathrm{O}$ & $\mathrm{CH}$ & $\mathrm{CH}$ & $\mathrm{C}-\mathrm{CH}_{2}$ & $\mathrm{CH}$ \\
\hline & & & & & & & & $\mathrm{CH}_{3}$ & \\
\hline \multirow[t]{3}{*}{4} & $\mathrm{CH}$ & $\mathrm{CH}$ & $\mathrm{C}-\mathrm{N}$ & $\mathrm{CH}$ & $\mathrm{C}=\mathrm{O}$ & $\mathrm{CH}$ & $\mathrm{CH}$ & $\mathrm{C}-\mathrm{Cl}$ & $\mathrm{CH}$ \\
\hline & & & $<\left(\mathrm{CH}_{2}\right)_{4}>$ & & & & & & \\
\hline & & & $\mathrm{N}-\mathrm{CH}_{3}$ & & & & & & \\
\hline 5 & $\mathrm{CH}$ & $-\mathrm{N}=$ & $\mathrm{C}-\mathrm{CH}_{3}$ & $-\mathrm{N}=$ & $\mathrm{C}=\mathrm{O}$ & $\mathrm{CH}$ & $\mathrm{CH}$ & $\mathrm{CH}$ & $\mathrm{CH}$ \\
\hline 6 & $\mathrm{CH}$ & $\mathrm{CH}$ & $\mathrm{CH}$ & $-\mathrm{CH}$ & $\mathrm{C}=\mathrm{O}$ & $\mathrm{CH}$ & $\mathrm{CH}$ & $\mathrm{CH}$ & $\mathrm{CH}$ \\
\hline \multirow[t]{2}{*}{7} & $\mathrm{CH}$ & $-\mathrm{N}=$ & $\mathrm{CH}$ & $-\mathrm{CH}$ & $\mathrm{C}=\mathrm{O}$ & $\mathrm{CH}$ & $\mathrm{CH}$ & $\mathrm{CCH}-$ & $\mathrm{CH}$ \\
\hline & & & & & & & & $\mathrm{C}_{7} \mathrm{H}_{16}$ & \\
\hline
\end{tabular}


Table 1. (continued)

\begin{tabular}{|c|c|c|c|c|c|c|c|c|c|}
\hline$\overline{8}$ & $-\mathrm{N}=$ & $\overline{\mathrm{CH}}$ & $\overline{\mathrm{CH}}$ & $-\mathrm{N}=$ & $\mathrm{C}=\mathrm{O}$ & $\mathrm{CH}$ & $\overline{\mathrm{CH}}$ & $\mathrm{CH}$ & $\overline{\mathrm{CH}}$ \\
\hline 9 & $\mathrm{CH}$ & $\mathrm{CH}$ & $\mathrm{CH}$ & $\begin{array}{l}\mathrm{C}- \\
\mathrm{OCH}_{3}\end{array}$ & $\begin{array}{l}\mathrm{C}=\mathrm{C}- \\
\text { phenyl }\end{array}$ & $\mathrm{CH}$ & $\mathrm{CH}$ & C-F & $\mathrm{CH}$ \\
\hline 10 & $\mathrm{CH}$ & $\mathrm{CH}$ & C-F & $\mathrm{CH}$ & $\mathrm{C}=\mathrm{O}$ & $\mathrm{CH}$ & $\begin{array}{l}\mathrm{C}-\mathrm{N} \\
<\left(\mathrm{CH}_{2}\right)_{4}> \\
\mathrm{N}-\mathrm{CH}_{3}\end{array}$ & $\mathrm{C}-\mathrm{F}$ & $\mathrm{CH}$ \\
\hline 11 & $\mathrm{CH}$ & $\mathrm{CH}$ & $\mathrm{CH}$ & $\mathrm{CH}$ & $-\mathrm{O}-$ & $\mathrm{CH}$ & $\mathrm{CH}$ & $\mathrm{CH}$ & $\mathrm{CH}$ \\
\hline 12 & $\mathrm{CH}$ & $-\mathrm{N}=$ & $\mathrm{CH}$ & $\mathrm{CH}$ & $-S-$ & $\mathrm{CH}$ & $\mathrm{CH}$ & $\mathrm{CH}$ & $\mathrm{CH}$ \\
\hline 13 & $\mathrm{CH}$ & $\mathrm{CH}$ & $\mathrm{CH}$ & $-\mathrm{N}=$ & $\mathrm{C}=\mathrm{O}$ & $\mathrm{CH}$ & $\mathrm{C}-\mathrm{Cl}$ & $\mathrm{CH}$ & $\mathrm{CH}$ \\
\hline 14 & $-\mathrm{N}=$ & $\mathrm{C}-\mathrm{OH}$ & $-\mathrm{N}=$ & $\mathrm{C}-\mathrm{OH}$ & $\mathrm{C}=\mathrm{O}$ & $\mathrm{CH}$ & $\mathrm{CH}$ & C-I & $\mathrm{CH}$ \\
\hline 15 & $\mathrm{CH}$ & $\mathrm{CH}$ & $\mathrm{CH}$ & $\mathrm{CH}$ & $\mathrm{C}=$ indole & $\mathrm{CH}$ & $\mathrm{CH}$ & $\mathrm{CH}$ & $\mathrm{CH}$ \\
\hline 16 & $\mathrm{CH}$ & $\mathrm{CH}$ & $\mathrm{CH}$ & $\mathrm{CH}$ & $\begin{array}{l}\mathrm{C}=\mathrm{C}-\mathrm{C}=\mathrm{C}- \\
\text { phenyl }\end{array}$ & $\mathrm{CH}$ & $\mathrm{CH}$ & $\mathrm{CH}$ & $\mathrm{CH}$ \\
\hline 17 & $\mathrm{CH}$ & $\mathrm{CH}$ & $\mathrm{CH}$ & $\mathrm{CH}$ & C-dioxane & $\mathrm{CH}$ & $\mathrm{CH}$ & $\mathrm{C}-\mathrm{Br}$ & $\mathrm{CH}$ \\
\hline \multicolumn{10}{|c|}{ Test set : } \\
\hline $1^{*}$ & $\mathrm{CH}$ & $-\mathrm{N}=$ & $\mathrm{CH}$ & $\mathrm{CH}$ & $\mathrm{C}=\mathrm{O}$ & $\mathrm{CH}$ & $\mathrm{CH}$ & $\begin{array}{l}\mathrm{C}- \\
\mathrm{C}_{8} \mathrm{H}_{17}\end{array}$ & $\mathrm{CH}$ \\
\hline 2 ' & $\mathrm{CH}$ & $\mathrm{CH}$ & $\mathrm{CH}$ & $-\mathrm{N}=$ & $\mathrm{C}=\mathrm{O}$ & $\mathrm{CH}$ & $\mathrm{CH}$ & $\mathrm{C}-\mathrm{Cl}$ & $\mathrm{CH}$ \\
\hline 3 ' & $\mathrm{CH}$ & $\mathrm{CH}$ & $\mathrm{CH}$ & $\mathrm{CH}$ & $\mathrm{C}=\mathrm{O}$ & $\mathrm{CH}$ & $\mathrm{CH}$ & $\mathrm{CH}$ & $\begin{array}{l}\mathrm{C}- \\
\mathrm{Cl}\end{array}$ \\
\hline 4' & $\mathrm{CH}$ & $\mathrm{CH}$ & $\begin{array}{l}\text { C-S- } \\
\mathrm{C}_{2} \mathrm{H}_{4} \mathrm{OH}\end{array}$ & $\mathrm{CH}$ & $\mathrm{C}=\mathrm{O}$ & $\mathrm{CH}$ & $\mathrm{CH}$ & $\mathrm{C}-\mathrm{Cl}$ & $\mathrm{CH}$ \\
\hline 5 , & $\mathrm{CH}$ & $-\mathrm{N}=$ & $\mathrm{CH}$ & $\mathrm{CH}$ & $\mathrm{C}=\mathrm{O}$ & $\mathrm{CH}$ & $\mathrm{CH}$ & $\mathrm{C}-\mathrm{C}_{4} \mathrm{H}_{9}$ & $\mathrm{CH}$ \\
\hline 6' & $\mathrm{CH}$ & $-\mathrm{N}=$ & $\mathrm{CH}$ & $\mathrm{CH}$ & $\mathrm{C}=\mathrm{O}$ & $\mathrm{CH}$ & $\mathrm{CH}$ & $\mathrm{C}_{2} \mathrm{H}_{5}$ & $\mathrm{CH}$ \\
\hline 7 ' & $\mathrm{CH}$ & $\mathrm{CH}$ & $\mathrm{CH}$ & $\begin{array}{l}\mathrm{C}- \\
\mathrm{OCH}_{3}\end{array}$ & $\mathrm{C}=\mathrm{O}$ & $\mathrm{CH}$ & $\mathrm{CH}$ & $\mathrm{CH}$ & $\mathrm{CH}$ \\
\hline $8^{\prime}$ & $\mathrm{CH}$ & $-\mathrm{N}=$ & $\mathrm{CH}$ & $\mathrm{CH}$ & $\mathrm{C}=\mathrm{O}$ & $\mathrm{CH}$ & $\mathrm{CH}$ & $\begin{array}{l}\mathrm{C}- \\
\mathrm{CHOC} \\
\mathrm{H}_{3} \mathrm{C}- \\
\left(\mathrm{CH}_{3}\right)_{2}\end{array}$ & $\mathrm{CH}$ \\
\hline 9' & $\mathrm{CH}$ & $\mathrm{CH}$ & $\mathrm{CH}$ & $\mathrm{CH}$ & $\mathrm{C}=\mathrm{O}$ & $\mathrm{CH}$ & $\mathrm{CH}$ & $\begin{array}{l}\mathrm{C}- \\
\mathrm{OCF}_{3}\end{array}$ & $\mathrm{CH}$ \\
\hline 10 ' & $\mathrm{CH}$ & $\mathrm{CH}$ & $\mathrm{CH}$ & $-\mathrm{N}=$ & $\mathrm{C}=\mathrm{O}$ & $\mathrm{CH}$ & $\mathrm{CH}$ & C-I & $\mathrm{CH}$ \\
\hline 11' & $\mathrm{CH}$ & $\mathrm{CH}$ & $\mathrm{CH}$ & $\begin{array}{l}\mathrm{C}- \\
\mathrm{OCH}_{3}\end{array}$ & $\mathrm{C}=\mathrm{O}$ & $\mathrm{CH}$ & $\mathrm{CH}$ & C-I & $\mathrm{CH}$ \\
\hline 12 ' & $\mathrm{CH}$ & $\mathrm{CH}$ & $\begin{array}{l}\mathrm{C} \text { - } \\
\text { piperidine }\end{array}$ & $\mathrm{CH}$ & $\mathrm{C}=\mathrm{O}$ & $\mathrm{CH}$ & $\mathrm{CH}$ & $\mathrm{C}-\mathrm{Cl}$ & $\mathrm{CH}$ \\
\hline
\end{tabular}


Table 1. (continued)

\begin{tabular}{llllllllll}
\hline $\mathbf{1 3}$ & $\mathrm{CH}$ & $-\mathrm{N}=$ & $\mathrm{CH}$ & $\mathrm{CH}$ & $\mathrm{C}=\mathrm{O}$ & $\mathrm{CH}$ & $\mathrm{CH}$ & $\mathrm{C}-\mathrm{Br}$ & $\mathrm{CH}$ \\
$\mathbf{1 4}$, & $\mathrm{CH}$ & $\mathrm{CH}$ & $\begin{array}{l}\mathrm{CNCH}_{3}(\mathrm{C} \\
\left.\mathrm{H}_{2}\right)_{2} \mathrm{OH}\end{array}$ & $\mathrm{CH}$ & $\mathrm{C}=\mathrm{O}$ & $\mathrm{CH}$ & $\mathrm{CH}$ & $\mathrm{C}-\mathrm{Cl}$ & $\mathrm{CH}$ \\
& & & & & & & \\
$\mathbf{1 5}$, & $\mathrm{CH}$ & $\mathrm{C}-$ & $\mathrm{CH}$ & $\mathrm{CH}$ & $\mathrm{C}=\mathrm{O}$ & $\mathrm{CH}$ & $\mathrm{CH}$ & $\mathrm{CH}$ & $\mathrm{CH}$ \\
& & & & & & & \\
\hline
\end{tabular}

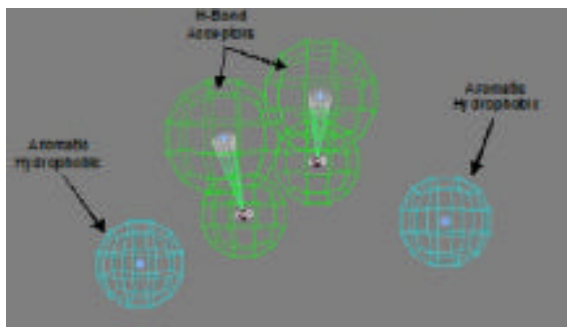

Fig. 1. Pharmacophore for antimalarial activity of the tryptanthrins
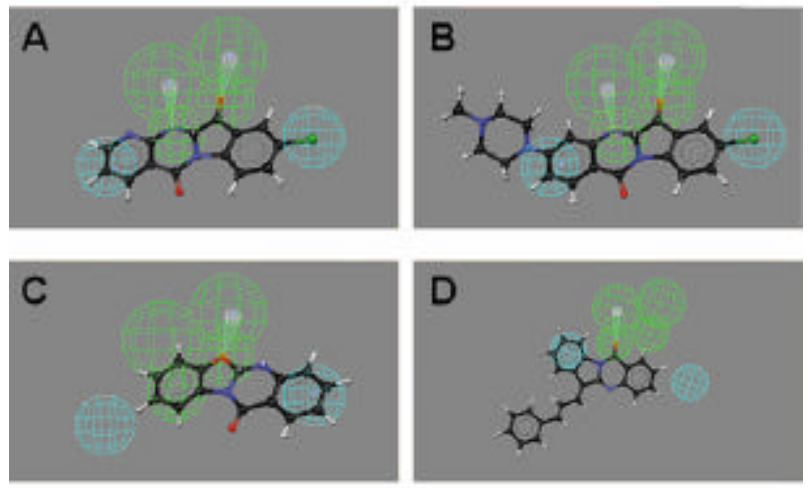

Fig. 2. Mapping of the more potent analogues: (a) $\underline{\mathbf{1}}$ and (b) $\underline{\mathbf{4}}$, and less potent analogues: (c) $\underline{\mathbf{1 1}}$ and (d) $\underline{\mathbf{1 6}}$, onto the pharmacophore model
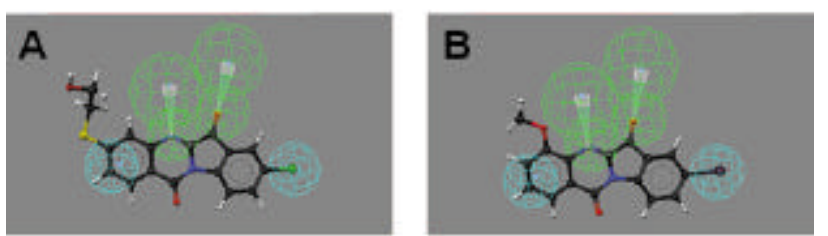

Fig. 3. Mapping of the more potent analogues: (a) $\underline{4}$ and (b) $\underline{\mathbf{1 1}}$ ' of the test set onto the pharmacophore 

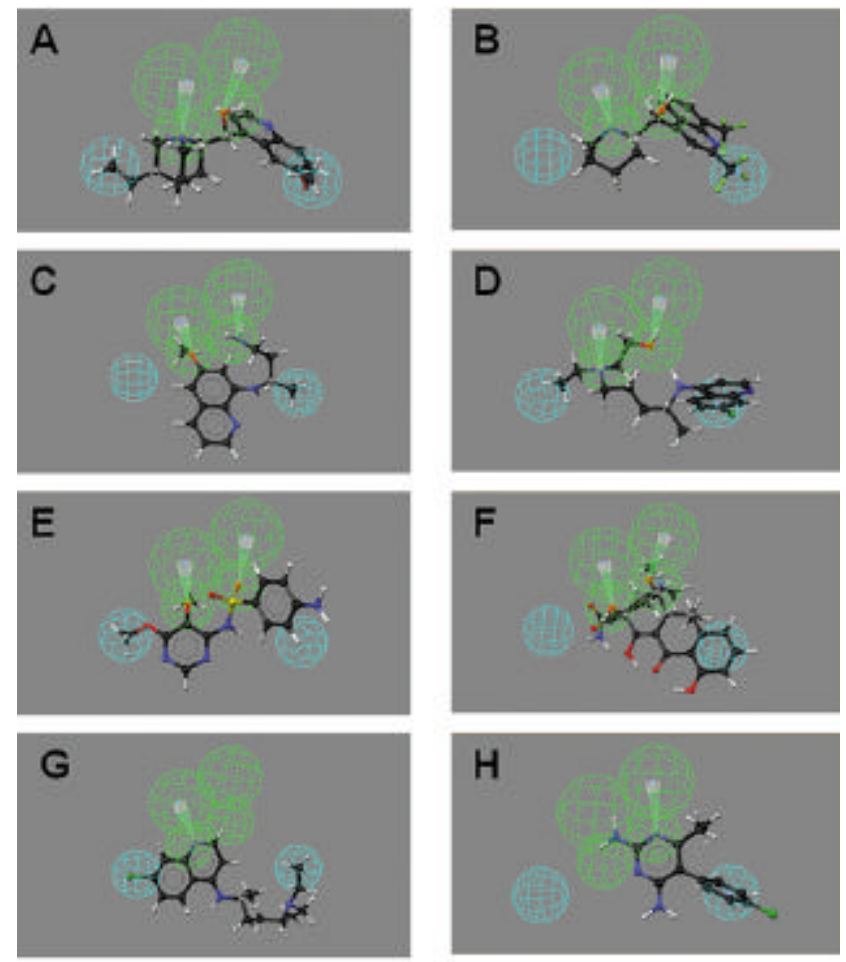

Fig. 4. Mapping of the pharmacophore onto eight commonly used antimalarial drugs in the United States: (a) quinine, (b) mefloquine, (c) primaquine, (d) hydroxyxhloroquine, (e) sulfadoxine, (f) doxycycline, (g) chloroquine, and (h) pyrimethamine
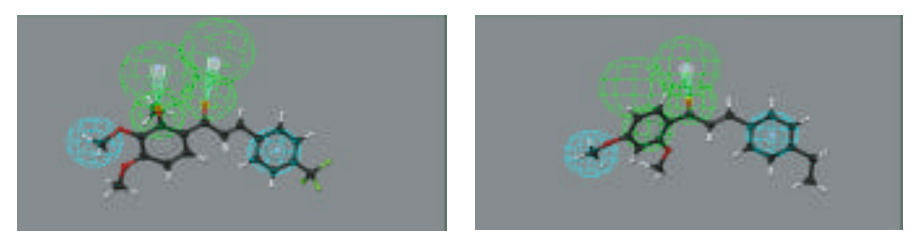

Fig. 5. Mapping of the pharmacophore on (a) 4,-trifluoromethyl-2',3',4'-trimethoxychalcone, and (b) 4-ethyl-2',4'-dimethoxychalcone
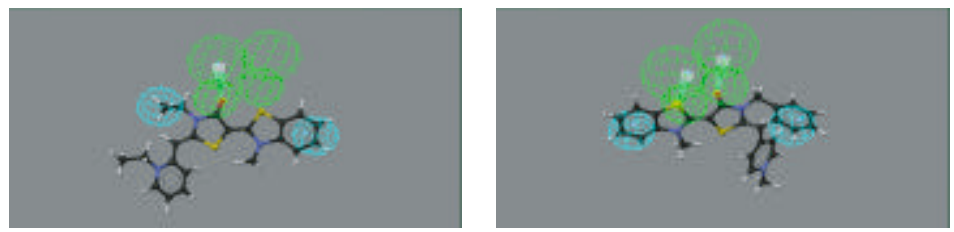

Fig. 6. Mapping of the pharmacophore on (a) rhodacyanine dye MKT-077 and (b) pararhodacyanine dye MKT-077 


\section{Conclusions}

The study demonstrates how the chemical features such as the hydrogen bond donors, acceptors, hydrophobicity etc. of potent compounds can be organized to develop pharmacophores for activity and utilize them for virtual in silico search of new class of compounds to open new chapters for chemotherapeutic study. Specifically, in this investigation we have shown how molecular characteristics from a set of diverse tryptanthrin derivatives may be organized to be both statistically and mechanistically significant for potent antimalarial activity that may have universal applicability. In addition, the resulting model can be used to unravel a possible rationale for the targetspecific antimalarial activity of these compounds. The validity of the pharmacophore extends to structurally different class of compounds, and thereby provides a powerful template from which novel drug candidates may be identified for extended study. Since the identity of the target for antimalarial activity of these compounds is unknown, the three-dimensional QSAR pharmacophore should aid in the design of well-tolerated target-specific antimalarial agents.

\section{Experimental Section}

Biological testing and procedure adopted for the pharmacophore generation utilizing the CATALYST [8] methodology is described earlier. [5]

\section{Acknowledgement}

The work was funded under a Military Infectious Disease Research Program grant. The opinions expressed herein are the private views of the authors and are not to be considered as official or reflecting the views of the Department of Army or the Department of Defense.

\section{References}

1. Malaria Foundation International, http://www.malaria.org/, and sites given therein.

2. Vroman, J.A., Gaston, M.A., Avery, M.A.: Current Progress in the Chemistry, Medicinal Chemistry and Drug Design of Artemisinin Based Antimalarials. Curr. Pharm. Design. 5 (1999) 101-138.

3. Bhattacharjee, A.K., Karle, J.M.: Stereoelectronic Properties of Antimalarial Artemisinin Analogues in Relation to Neurotoxicity. Chem. Res. Toxicol. 12 (1999) 422- 428.

4. Bhattacharjee, A.K., Hartell, M.G., Nichols, D.A., Hicks, R.P., Stanton, B., van Hamont, J.E., Milhous, W.K.: Structure-activity relationship study of antimalarial indolo [2,1b]quinazoline-6-12-diones (tryptanthrins). Three dimensional pharmacophores modeling and identification of new antimalarial candidates. European J. Med. Chem. 39 (2004) 59-67.

5. Buchwald, P., Bodor, N.: Computer-aided drug design: the role of quantitative structureproperty, structure-activity and structure-metabolism relationships (QSPR, QSAR, QSMR). Drug Future. 27 (2002) 577-588. 
6. Bhattacharjee, A.K., Kyle, D.E., Vennerstrom, J.L., Milhous, W.K.: A 3D QSAR Pharmacophore Model and Quantum Chemical Structure Activity Analysis of Chloroquine(CQ)Resistance Reversal. J. Chem. Info. Comput. Sci. 42 (2002) 1212-1220.

7. Bhattacharjee, A.K., Geyer, J. A., Woodard, C.L., Kathcart, A.K., Nichols, D.A., Prigge, S.T., Li, Z., Mott, B.T., Waters, N.C.: A Three Dimensional In Silico Pharmacophore Model for Inhibition of Plasmodium Falciparum Cyclin Dependent Kinases and Discovery of Different Classes of Novel Pfmrk Specific Inhibitors. J. Med. Chem. 47 (2004) 5418-5426.

8. CATALYST Version 4.5 software, 2000, Accelrys Inc., San Diego, CA.

9. Slater, A.F.G., Cerami, A.: Inhibition of chloroquine of a novel haem polymerase enzyme activity in malaria trophozoites. Nature 355 (1992) 167-169.

10. Meshnick, S.R.: In Malaria Parasite Biology, Pathogenesis and Protection: From quinine to qinghaosu: historical perspectives. Sherman, I.W. (eds.): ASM Press, Washington, D.C. (1998) 341-353.

11. Liu, M., Wilairat, P., Go, M.L.: Antimalarial alkoxylated and hydroxylated chalcones: structure-activity relationship analysis. J. Med. Chem. 44 (2001) 4443-4452.

12. Takasu, K.; Inoue, H.; Kim, H.K.; Suzuki, M.; Shishido, T.; Wataya, Y.; Ihara, M. Rhodacyanine dyes as antimalarials. 1. Preliminary evaluation of their activity and toxicity. J. Med. Chem. 45 (2002) 995-998. 